\title{
ARTIKELEN
}

\section{Actieve rechtvaardigheid}

\section{Herstelrecht als vruchtbare bodem voor de uitoefening van burgerschap}

\author{
Brunilda Pali
}

\section{Introductie}

De reflecties in deze bijdrage zijn gebaseerd op het conceptuele werk dat verricht is gedurende het eerste jaar van ALTERNATIVE ${ }^{1}$, een project gecoördineerd door de Katholieke Universiteit Leuven. Het overkoepelende doel van dit project is om een alternatief en verdiept begrip van veiligheid en rechtvaardigheid te verkrijgen op basis van empirisch onderzoek over de dimensies, dynamieken en uitkomsten van actieve burgerparticipatie bij de verwerking of oplossing van conflicten in interculturele contexten. Het project focust conceptueel op vier vervlochten relaties: de eerste is de relatie tussen vertogen over justitie en over veiligheid, de tweede is de relatie tussen herstelrecht en interculturaliteit, de derde is de relatie tussen actieonderzoek en theorievorming, en de vierde is die tussen herstelrecht en actieve participatie, burgerschap en democratie.

Dit artikel zal zich vooral richten op de relatie tussen het concept van burgerschap en het herstelrecht, in het bijzonder zoals gezien en uitgewerkt in de vier interculturele settings van het ALTERNATIVE-project ${ }^{2}$. De bijdrage is gestructureerd in vier paragrafen. In de eerste zal ik ingaan op het concept van participerend burgerschap in relatie tot criminaliteit en conflicten. In de tweede zal ik de claim die het vertoog van het herstelrecht neerlegt met betrekking tot participerend burgerschap en democratie uitleggen en toelichten. In paragraaf $3 \mathrm{zal} \mathrm{ik}$ enkele van de uitdagingen aan het herstelrechtelijk vertoog behandelen die de relatie tussen herstelrecht en participerend burgerschap compliceren. In paragraaf 4 zal ik enkele van de manieren uitwerken waarop het ALTERNATIVE-pro-

1 ALTERNATIVE wordt gesubsidieerd door de Europese Commissie als onderdeel van de Seventh Framework Programme (FP7). Voor meer informatie over het project, zie de website www.alter nativeproject.eu.

2 De kern van het ALTERNATIVE-project wordt gevormd door vier intensieve case studies in verschillende interculturele contexten, in de vorm van actieonderzoek. De conflicten die de vier geselecteerde interculturele contexten kenmerken zijn: 1. Conflicten tussen residentiële burgers en burgers met een migratieachtergrond in wijken met sociale huisvesting in Wenen; 2. Conflicten tussen Roma en niet-Roma inwoners in een kleine stad in Hongarije; 3. Conflicten in drie multi-etnische en multiculturele regio's in Servië: tussen Serviërs en Albanezen, Serviërs en Moslims, en Serviërs en Kroaten; 4. Conflicten op drie verschillende locaties in Noord-Ierland: tussen een lokale gemeenschap en jeugdbendes, tussen gesettelde bewoners en recent aangekomen immigranten, en sektarische conflicten tussen verschillende gemeenschappen. 
Brunilda Pali

ject enkele van deze uitdagingen aangaat. Ik sluit de bijdrage af met enkele overkoepelende observaties.

\section{Over participerend burgerschap}

Het concept burgerschap herinnert aan een op het bestaan van de staat gebaseerde definitie waarin burgerschap de betekenis heeft van een formeel lidmaatschap van een politieke eenheid, meestal de natiestaat. Op die manier opgevat wordt burgerschap een concept met onderscheidende eigenschappen, waardoor een grens wordt getrokken tussen degenen die tot die eenheid behoren en zij die daar niet toe behoren. Holston (2008) betwijfelt deze definitie van burgerschap door deze te verbinden met de ervaring van burgers. Vanuit dit gezichtspunt, gaat burgerschap niet alleen maar over de wettelijke status van lidmaatschap, maar ook over het gevoel van het individu dat hij tot de samenleving hoort en daarin thuis is. Tegelijkertijd heeft burgerschap niet alleen maar betrekking op het recht om te participeren aan de politiek, aan de debatten over de inrichting van de maatschappij, maar ook in andere domeinen van het maatschappelijk leven. Terwijl actief en participerend burgerschap zeer wordt gewaardeerd in de Europese context en een rijk concept is in sociologische theorieën, zoals verkend binnen studies over 'deliberatieve democratie' (Dryzek, 2010; Elster, 1998), 'nodal governance' (Froestad en Shearing, 2007; Shearing en Wood, 2003), 'dominion' (Braithwaite en Pettit, 1992), en 'civil society' (Giddens, 1998), is het concept nog niet inhoudelijk verbonden met bestaande, voor het leven van mensen belangrijke alledaagse praktijken. In dit opzicht bieden de samenlevingssferen waarin mensen zich geraakt weten en voelen door criminaliteit en conflict een vruchtbare bodem voor een dieper begrip.

Tot nu toe is onduidelijk in welke mate, en door welke interactieve processen, Europese burgers in staat zijn om hun rechten en verantwoordelijkheden uit te oefenen als het gaat om criminaliteit en conflicten. Criminaliteit verwijst duidelijk naar een spanningsveld tussen de rol van de staat bij het ontwikkelen van top-down criminaliteitsbeleid (of rechtshandhavingsbeleid), en de rol van burgers de 'civil society' in het uitoefenen van bottom-up participerend burgerschap (Braithwaite en Parker, 1999). Wanneer mensen zeer zwaar en uitsluitend leunen op de statelijke autoriteiten en wanneer staatsinstanties worden aangezien als de enige institutionele verantwoordelijken voor sociaal-economisch welzijn, is het resultaat een grote passiviteit van de burgers in een dergelijke samenleving. $\mathrm{Zij}$ lijken de status van onderdaan te accepteren, of zelfs te prefereren boven die van actieve burgers. Om die reden wordt het uitdagend om manieren te vinden waarbij mensen worden gestimuleerd om een meer directe rol te spelen in het omgaan met conflicten, waarbij ze worden gemotiveerd om zich meer bewust te worden van de sociale problemen om hen heen, en hen aan te moedigen betrokken te raken in publieke kwesties.

Actuele trends in sociologische en politicologische theorievorming wijzen op een mondiale nadruk op democratische participatie, op de inclusie van burgers in 
besluitvormingsprocessen, op het vertrouwen in en het gebruikmaken van dialoog in het omgaan met conflicten, en op de ontwikkeling van sociaal kapitaal. Terwijl de meeste West-Europese landen hun vertrouwen stellen in staatsinstanties in het algemeen, en meer in het bijzonder in het professionalisme en de legitimiteit van het strafrechtelijk systeem, is er tegelijkertijd een recente trend overeenkomend met de mondiale ontwikkelingen, naar de opname van burgers in de vorming van publiek beleid en naar het dichten van de kloof tussen de staat en de burgers. Shapland (2008: 26) betoogt dat 'de toekomst de ontwikkeling zal laten zien van nieuwe vormen van wederzijdse aanpassing rond communicatie, partnerschap, en van vele onderscheiden vormen van omgaan met criminaliteit', tussen maatschappelijke organisaties, strafrecht, samenlevingsgroepen en burgers.

\section{Herstelrecht als participerende rechtvaardigheid}

Tegen deze achtergrond kunnen herstelrechtelijke benaderingen een belangrijke bouwsteen en een sociaal-educatief instrument zijn in een ruimere beweging naar participerend burgerschap in de Europese context. Het herstelrecht biedt een reflectief vertoog over recht doen dat het herstellen van de schade, veroorzaakt door criminaliteit, benadrukt en dat criminaliteit beziet als meer omvattend dan een simpele schending van het recht. Erkennend dat criminaliteit (materiële, sociale, psychologische en relationele) schade aan mensen en de samenleving toebrengt, staat het herstelrecht erop dat het recht gericht is op het repareren van die vormen van schade en dat de partijen toegestaan wordt te participeren in dat proces - meestal in face-to-face ontmoetingen met behulp van een mediator of facilitator. Herstelrechtelijke programma's stellen daarom het slachtoffer, de dader en de geraakte andere leden van de samenleving in staat om direct betrokken te zijn in het formuleren van de reactie op het misdrijf.

De eis van actieve participatie van de betrokkenen, geraakt door het conflict of het criminele feit, is in het herstelrechtelijke denken geplaatst in het kader van een streven naar een samenleving waarin de vervreemding zou kunnen worden overwonnen. Christie's baanbrekende artikel Conflicts as property (1977) tekende een participatieve benadering van recht doen uit die een remedie zou bieden tegen sociale segregatie en het verlies van sociale cohesie en mogelijkheden zou bieden voor onderlinge norm verheldering. Christie betoogde dat de actieve participatie in het omgaan met conflicten en hun gevolgen, voordelen biedt aan zowel het slachtoffer, de dader als de samenleving, en als zodanig bieden conflicten een aanleiding en een potentieel voor activiteit en participatie. De ruimere politieke implicaties van actieve participatie van de direct betrokkenen worden gezien in de bevordering van democratische waarden en in het dienen als oefenterrein voor democratische praktijk. Bij voorbeeld, in Civic implications of restorative justice theory: citizen participation and criminal justice policy (2003) wees Dzur op een ruimer en meer ambitieus doel voor het herstelrecht, namelijk het beïnvloeden en hervormen van strafrechtelijk beleid en, nog ruimer, de bevordering van deliberatieve democratie in de samenleving. Daarop aansluitend heeft Braithwaite in zijn 
inspirerende boek Restorative justice and responsive regulation (2002) herstelrechtelijke benaderingen onder de aandacht gebracht waarin het vermogen om adequate antwoorden op sociale conflicten te formuleren wordt vergroot.

Herstelrechtelijke wetenschappers zien herstelgerichte praktijken als 'small experiments of deliberative democracy' (Braithwaite, 2000; Christie, 1977; Dzur en Olson, 2004). Zij betogen dat deze micro-ervaringen van democratie ons kunnen leren hoe we actieve burgers kunnen worden. In de woorden van Braithwaite, 'Disputing over daily injustices is where we learn to become democratic citizens' (1999, 78). Participatie kan ook bijdragen aan het ontstaan van democratische gewoonten en aan een groter begrip van democratische mogelijkheden, met inbegrip van de erkenning van de rol van de civil society in het bestuur (Gordon, 2006). Herstelrecht roept om een verschuiving in de 'essentiële rol van de burger van ontvanger van diensten naar besluitvormer met een belang in welke diensten worden aangeboden en hoe dat gebeurt' (Bazemore 1998, 334). Het biedt de samenleving een forum 'waardoor zij haar verantwoordelijkheid voor haar leden kan nemen in plaats van passief te lijden onder criminaliteit en volledig afhankelijk te zijn van de dwang van de staat als het gaat om orde en bescherming' (Schweigert 1999, 33). Als zodanig zou herstelrecht moeten worden nagestreefd als een tegenbeweging die zich richt op de repercussies van de moderne staat en van het bureaucratisch bestuurmodel (zoals in het strafrechtelijke systeem), vooral in verband met een soort van vervreemding die het effect is van institutionalisering en bureaucratisering; door het in het leven roepen van democratische, dialogische procedures en praktijken kunnen die (uitsluitende en vervreemdende) effecten worden overwinnen.

Deze opvatting van participatie leidt tot het begrip dat herstelrecht helpt in het uitwerken en vergroten van wat Hannah Arendt 'onze plaats in de wereld' noemt in The human condition (1958): een plaats die mensen toelaat de vrijheid te nemen om een actieve deelnemer te zijn aan een politiek systeem. Bij elkaar komen en 'politiek handelen' zijn, volgens haar, de essentie en de meest waardevolle expressie van onze menselijke conditie. Als we herstelrechtelijke praktijken op die manier opvatten als samenkomen en samen handelen, dan worden ze manifestaties van politiek handelen (Pali en Pelikan, 2010).

\section{Huidige beperkingen van het herstelrechtelijke debat inzake participatie}

Momenteel is het domein herstelrecht in Europa goed beschreven, geanalyseerd en theoretisch onderzocht en wordt de potentie van herstelrecht erkend door praktijkmensen, wetenschappers en beleidsmakers, zowel op nationaal als op supranationaal niveau. Niettemin wordt herstelrecht geconfronteerd met twee belangrijke beperkingen. Ten eerste het inadequate en statische gebruik van het concept gemeenschap. Ten tweede het onvermogen om een concrete link te leggen tussen en een analyse te maken van het macro- en microdomein, waardoor herstelrecht een individueel en persoonsgebonden discours blijft over criminaliteit en rechtvaardigheid. 
Actieve rechtvaardigheid

\section{Bezwaren tegen het concept gemeenschap binnen herstelrecht}

In de literatuur over herstelrecht wordt een notie van gemeenschap verondersteld die zich laat omschrijven als homogeen, verbonden, functioneel, harmonieus, coherent, empowered, democratisch, accommoderend, inclusief en op consensus gericht (Pavlich, 2005). Zo word er bijvoorbeeld bij discussies over de re-integratie van de dader uitgegaan van een prosociale gemeenschap, waarin daders geïntegreerd kunnen worden en waarbij burgers binnen die gemeenschap in staat zijn om de dader te vergeven (Walgrave, 2002).

Binnen dit ideaalbeeld is geen ruimte voor diversiteit en conflict, hiërarchie en verschillende machtsrelaties (Pavlich, 2005). Herstelrecht gaat ervan uit dat verschillende perspectieven verenigd kunnen worden, dat leden van een gemeenschap dezelfde waarden en opvattingen delen en dat zij gelijk zijn aan anderen (Hudson, 2003). Dit terwijl niet alle gemeenschappen dezelfde middelen hebben en verschillen in de mate waarin zij het leed van slachtoffers kunnen herstellen of daders kunnen re-integreren binnen de gemeenschap. Gemeenschappen verschillen in de mate waarin ze in staat zijn om op basis van wederzijds vertrouwen te opereren en de mate waarin ze bereid zijn om te opereren vanuit het algemeen belang. Ook zijn er verschillen in de relaties die lokale instituties binnen gemeenschappen onderhouden met de bredere samenleving, in termen van macht en middelen (Crawford, 1997; Cunneen en Hoyle, 2010).

Een andere mythe binnen het communitaristische herstelrecht heeft betrekking op de sterke nadruk op sociale controle en het reconstitueren van de gemeenschap. In essentie bestendigt een dergelijke mythe het idee dat hoe organischer een gemeenschap is, hoe minder criminaliteit er zal plaatsvinden. Dit is een aantrekkelijke gedachte die tegelijkertijd ook nostalgisch en onnodig is. Er zijn veel verschillende casussen bekend, waarbij de organische gemeenschap criminaliteit ondersteunde en niet organische gemeenschappen met lage criminaliteitscijfers hadden.

Crawford heeft betoogd dat herstelrecht niet toekomt aan het erkennen van de donkere kant van organisch sociaal kapitaal (Crawford, 1997, 2010). Volgens hem zijn sterke banden en sociale netwerken niet gelijk aan conformiteit, of aan de andere kant, sterke sociale verbanden kunnen ook criminaliteit genereren, denk aan georganiseerde criminaliteit en bende culturen. Met andere woorden, afwijkende sociale netwerken kunnen vormen van antisociaal gedrag bestendigen door waarden, vaardigheden en kennis door te geven die crimineel kapitaal constitueren (Crawford, 2010). Dit veronderstelt volgens Crawford een behoefte aan een normatieve dimensie van sociaal kapitaal en gemeenschapswaarden.

De utopische visie van een gemeenschap als een verloren Utopia is nauw gerelateerd aan het concept herstelrecht, dat geassocieerd wordt met waarden als heelheid, harmonie, vrede, genezen, gezondheid, reparatie, restitutie en re-integratie. Zehr beargumenteert dat als criminaliteit schade veroorzaakt, herstelrecht zich dient te richten op herstel en heel worden (healing). Volgens Zehr verstoort criminaliteit twee basisveronderstellingen waarop we ons leven baseren, namelijk dat de wereld een ordelijke en betekenisvolle plek is en ons geloof in onze persoonlijke autonomie. Beide veronderstellingen zijn essentieel voor het begrip 
heelheid ('wholeness') (Zehr, 1990: 24). Het belangrijkste doel van herstelrecht is dan ook om de gemeenschap te herstellen door effectief om te gaan met de behoeften van slachtoffers, het succesvol integreren van daders en het bouwen van gemeenschapskracht door gemeenschappen te leren om te gaan met criminaliteit door de toepassing van herstelgericht processen (Pavlich, 2005).

Het discours / vertoog over heel worden en een helend equilibrium veronderstelt de aanwezigheid van een gemeenschapsgeoriënteerde, gezonde orde (Pavlich, 2005: 36) waarbij herstelrecht die orde herstelt, oftewel de ideale condities terugbrengt.

In het licht van deze kritieken zou herstelrecht 'mindful' moeten zijn, zoals Pavlich stelt, en dat het beroep op de gemeenschap altijd een ethische kwestie is, die een continue, open en toekomstgerichte aspiratie is hoe om te gaan met anderen en met de gemeenschap. Het begrip gemeenschap is in die zin een open en lopende activiteit in plaats van een afgesloten entiteit, die hersteld of bewaard dient te worden (Pavlich, 2005; Young, 2000; Agamben, 1993). Zowel volgens Pavlich als Crawford dient de notie van gemeenschap bekeken te worden in de context van machtsrelaties en haar veronderstellingen, en is in die zin een fundamenteel onderdeel van een progressief herstelgericht programma. Het is dan ook beter om te spreken van transformeren van gemeenschappen in plaats van het herstellen van gemeenschappen (Pavlich, 2005; Crawford, 1997, 2010).

\section{Rechtvaardigheid en sociale problemen}

Een andere belangrijke uitdaging voor herstelrecht is het gebrek aan een verbinding tussen het micro- en het macrodomein. Binnen herstelgerichte praktijken wordt het beroep op gemeenschap veelal niet in verband gebracht met de bredere maatschappelijke en politiek economische context, waarmee de individuele dader en het slachtoffer zijn verbonden. De meeste critici hebben beargumenteerd dat herstelrecht alleen refereert aan het directe conflict, zonder dit conflict te situeren in een bredere sociale en structurele context. Herstelrecht in algemene zin heeft nagelaten om zorgen over sociale rechtvaardigheid te adresseren; het betrok criminaliteit uitsluitend op het individu en zag rechtvaardigheid als een exclusief alternatief voor straf, zonder het in verband te brengen met de meer complexe politieke betekenis van rechtvaardigheid. Het wordt belangrijk om herstelrecht theoretisch te doordenken, binnen de bredere context van de sociale wetenschappen, die meer focussen op sociale en participerende rechtvaardigheid en minder op straffende rechtvaardigheid. Herstelrecht individualiseert criminaliteit en geeft prioriteit aan persoonlijke verantwoordelijkheid. Om die reden kan herstelrecht ook gezien worden als een discours dat overeenkomsten vertoont met het neoliberale discours met haar nadruk op actieve verantwoordelijkheid van individuele burgers. Neomarxistische critici wijzen op de huidige tendensen naar meer verantwoordelijkheid van burgers, als onderdeel van het streven naar een terugtredende overheid. Zij wijzen erop dat de staat daarentegen eerst de sociale wonden zou moeten helen, voordat de samenleving kan participeren in een inclusieve politiek van criminaliteitsbestrijding (Young, 2000).

Door het individualiseren van criminaliteit verliest herstelrecht de factoren uit het oog die buiten de invloedssfeer van de dader liggen. Het laat daarmee de so- 
ciaal-economische oorzaken van criminaliteit buiten beschouwing (Price, 2004). Herstelrecht biedt geen strategie om de oorzaken van criminaliteit te elimineren, zoals deprivatie en sociale ongelijkheid, en individualiseert daarmee criminaliteit in termen van verantwoordelijkheid en de daarmee samenhangende remedies. De vraag is of herstelgerichte initiatieven wel geschikt zijn om de achterliggende structurele ongelijkheden te verminderen die samenlevingen verdelen en criminaliteit bevorderen (LaPrairie, 1995; Braithwaite, 1999). Tenslotte hebben feministische en postkoloniale critici eraan herinnerd dat de focus op de gemeenschap binnen herstelrecht bestaande machtsstructuren - patriarchaal en koloniaal kan versterken (Gaarder en Presser, 2008; Cunneen, 2008).

De belofte van herstelrecht ten aanzien van samenwerking en participatie van burgers blijft doorgaans beperkt tot betrokken 'communities of care'. Een van de belangrijkste uitdagingen zoals Polk beargumenteert met betrekking tot het conferencing model, is het gebrek aan focus op institutionele interventies, waaronder werk, school, huisvesting en gezondheid. Het herstelrecht zou zich ook niet moeten beperken tot discursieve en reflexieve aspecten, maar allianties moeten aangaan met gouvernementele en non-gouvernementele organisaties, en daarmee een gezamenlijke verantwoordelijkheid moeten nemen teneinde sociale en politieke actie te ondernemen tegen sociale onrechtvaardigheid. Sommigen hebben beargumenteerd dat herstelrecht niet alleen die sociale veranderingen kan bewerkstelligen, maar dat hulp nodig is van andere sociale praktijken en bewegingen. Sociale verandering en sociale rechtvaardigheid is een enorme taak die samenwerking tussen verschillende sectoren en actoren binnen de civil society vergt.

\section{De alternatieven van het ALTERNATIVE project}

In het licht van de vastgestelde beperkingen en mogelijkheden van participatief burgerschap en herstelgerichte benaderingen beoogt het ALTERNATIVE project het concept van de actieve rechtvaardigheid te bevorderen. Dat gebeurt door het verkennen en het versterken van de relatie tussen actief burgerschap en rechtvaardigheid en wordt onderzocht in herstelrechtelijke processen door het gebruik van actieonderzoek. Binnen het ALTERNATIVE project wordt het belangrijk geacht om trends van maatschappelijke ontwikkelingen te onderzoeken en analyseren die in de richting wijzen van actieve participatie van burgers in de afhandeling van hun eigen conflicten, en die top-down strategieën van regulering van conflicten verbinden met bottom-up initiatieven via open participatieve processen. Dit impliceert enerzijds het begrijpen van de historische, sociaaleconomische, politieke en culturele verschillen in Europa met betrekking tot de begrippen van gemeenschap, civil society en actief burgerschap, met name met betrekking tot conflictregulering. Aan de andere kant impliceert het dat de spanningen op het gebied van strafrechtelijk beleid vastgesteld dienen te worden, spanningen die kunnen wijzen op zowel een versterking van actief burgerschap als een beperking van actief burgerschap. De vier geselecteerde landen wijzen op grote verschillen in dit opzicht. Bijvoorbeeld, post-conflict landen zoals Noord-Ierland en Servië ver- 
tonen bepaalde overeenkomsten vanwege hun conflictueuze geschiedenis, terwijl Servië en Hongarije overeenkomsten vertonen vanwege hun post - communistische erfenis. Tegelijkertijd is het van belang om de bestaande mechanismen van rechtvaardigheid en meervoudige betekenissen van rechtvaardigheid in enkele interculturele Europese settings vast te stellen en te analyseren. Nagegaan dient te worden in welke mate herstelrechtelijke participatieprojecten invloed hebben op de attitudes van participanten ten aanzien van rechtvaardigheid.

Zoals eerder vermeld omvat ALTERNATIVE vier intensieve case studies in verschillende interculturele contexten. De conflicten die kenmerkend zijn voor de vier geselecteerde contexten zijn:

1. conflicten tussen bewoners met en zonder migrantenachtergrond in wijken met sociale huisvesting in Wenen;

2. conflicten tussen Roma en niet-Roma burgers in een klein stadje in Hongarije;

3. conflicten binnen drie multi-etnische en multiculturele regio's in Servië: tussen Serviërs en Albanezen, Serviërs en moslims en Serviërs en Kroaten;

4. conflicten op drie verschillende locaties in Noord-Ierland: tussen een lokale gemeenschap en jeugdbendes, tussen langdurig ingezetenen en recente immigranten, en interculturele sektarische conflicten.

Het project identificeert eerst de bestaande rechtvaardigheidsmechanismen (formeel en informeel) in elk van deze settings, en ten tweede beoogt het activiteiten op te starten teneinde sociale conflicten te beheersen. Door zich te richten op interculturele settings, beoogt ALTERNATIVE de mogelijkheden van mediationdiensten en herstelgerichte modellen te verkennen. Het gaat om maatschappelijke conflicten die niet door het strafrechtelijk systeem worden doorverwezen naar deze diensten, zoals conflicten die plaatsvinden binnen een multi-etnisch dorp. Aan de andere kant beogen de mediationdiensten samenwerkingsverbanden met diverse maatschappelijke organisaties te bevorderen, bijvoorbeeld interculturele organisaties of welzijnsdiensten. Op die manier wordt dus afgestapt van een smalle benadering van conflictbemiddeling. In alle settings werken bemiddelingsdiensten samen met onderzoeksinstituten en diverse lokale organisaties teneinde conflicten met vele betrokken actoren samen aan te pakken.

Ons project maakt gebruik van de actieonderzoekmethodologie omdat noch het onderwerp van actieve participatie, noch een complex begrip van (herstellende) rechtvaardigheid kan worden benaderd door middel van conventionele onderzoeksmethoden, zoals desk research of bevolkingsenquêtes. Dergelijke onderwerpen vereisen vormen van onderzoek waarin de onderzoekers zelf deel uitmaken van het proces. Dit soort onderzoek wordt geacht tegelijk praktijk, theorie en de maatschappij te beïnvloeden. Het betreft eigenlijk een bepaalde periode van onderzoek, waarin sociale situaties worden beschreven, geïnterpreteerd en uitgelegd, tijdens het uitvoeren van activiteiten waarbij zowel onderzoekers, praktijkprofessionals als burgers betrokken zijn. Het participatieve proces omvat een dynamische aanpak, waarbij conceptualisering, probleemidentificatie, planning, activiteiten en evaluatie met elkaar verbonden zijn in een cyclisch proces (Stringer, 1999). 
In alle vier de settings werken de onderzoekers samen met bemiddelingsdiensten en andere belangrijke lokale actoren, om de geplande activiteiten uit te voeren. Deze activiteiten worden bottom-up gepland en afgestemd op de specifieke omstandigheden. Bijvoorbeeld in Wenen vinden de activiteiten plaats binnen een raad voor sociale huisvesting. In de workshops in Servië worden de verschillende gemeenschappen bewust bij elkaar gebracht. In Noord-Ierland speelt de universiteit een belangrijke rol als neutrale en tegelijkertijd vertrouwde instantie die het voortouw van conflictregulering neemt. In Hongarije moet eerst langzaam vertrouwen worden opgebouwd, alvorens de Roma gemeenschap volledig kan/wil participeren. In het project fungeert het concept 'nodal governance 'zoals ontwikkeld door Shearing en Wood (2003) als kader om participatieve manieren van conflictregulering te ondersteunen. Deze auteurs betogen dat besturen vandaag de dag wordt gekenmerkt door een veelheid aan actoren die tezamen min of meer onderling verbonden governance-netwerken vormen. Het begrip 'nodal governance' - en netwerktheorieën in het algemeen - is tot dusver niet gebruikt door herstelrechtelijke onderzoekers. Velen onder hen blijven doorgaan met het nogal verouderde en nostalgische concept van 'gemeenschap', vooral onder invloed van het communitarisme.

De literatuur over gemeenschap binnen herstelrecht is overwegend Anglo-Amerikaans en gebaseerd op de theorie van de 'community justice'. In ons project gaan we ervan uit dat in de Europese context, in tegenstelling tot een dergelijke theorie, herstelrechtelijke diensten nauw verbonden zijn met het strafrechtelijk systeem en wetgeving. Dat is de reden waarom Europese landen vanaf het begin geprobeerd hebben om herstelrecht in een justitieel kader onder te brengen en programma's te creëren onder toezicht van de overheid (of in NGO-achtige structuren die nauw samenwerken met 'de staat') (Willemsens en Walgrave, 2007). Bijgevolg is burgerschap, en niet gemeenschap, een beter te benutten concept. We creëren in ALTERNATIVE interactieve settings waarin zowel informele als formele benaderingen van rechtvaardigheid kunnen worden benut, alsmede mechanismen van rechtvaardigheid op individueel en op maatschappelijk niveau (Aertsen, 2001, 2008). Bijvoorbeeld in Wenen wordt het onderzoek uitgevoerd in een buitengerechtelijke setting, wat een nieuw idee is binnen de Oostenrijkse context.

Onderzoek in Europa was vooral gericht op VOM-bemiddeling (Aertsen et al., 2004, Vanfraechem et al., 2010) en, in mindere mate, op conferencing (Zinsstag et al., 2011; Zinsstag en Vanfraechem, 2012). Tot op heden hebben peace making circles, sociale bemiddeling en andere alternatieve modellen van conflictregulering weinig aandacht gekregen, terwijl juist deze modellen een groot potentieel bieden als het gaat om de aanpak van criminele incidenten en conflicten die de bredere samenleving beïnvloeden, onder andere in de sfeer van multi-etnische en interreligieuze spanningen.

Als herstelrecht een geschikt instrument wil worden om sociaal kapitaal en lokale en praktische kennis te benutten, zullen bredere modellen moeten worden verkend (CEPEJ, 2007; Pali en Pelikan, 2010). Deze bredere modellen van herstelrecht zouden in staat moeten zijn om antwoorden te bieden op aanhoudende interculturele conflicten; dergelijke modellen kunnen de theorie en praktijk van 
herstelrecht verder ontwikkelen, en gaan de individualisering van misdaad en de daarop afgestemde remedies voorbij.

Zo zal de samenwerking tussen de bemiddelingsdiensten en andere belangrijke lokale organisaties bij de aanpak van conflicten ervoor zorgen dat de verschillende capaciteiten en de habitus van elk van deze organisaties door andere zullen worden benut. Dat bevordert uitwisseling, dialoog en leervermogen. De verscheidenheid van conflicten dwingt bemiddelingsdiensten ertoe op maat organisaties op te bouwen en uiteenlopende creatieve strategieën toe te passen. Bijvoorbeeld, in Hongarije, wordt eerst begonnen met activiteiten gericht op een langetermijnopbouw van vertrouwen, inclusief openbare debatten in de dorpsraad, verkiezingen en gedurende de eerste twee jaren maandelijks overleg binnen een communicatieplatform. Pas daarna kan met conflictbeheersing worden begonnen. Deze programmering wijkt in sterke mate af van de eenmalige interventie die meestal is gepland binnen een standaardbemiddeling.

\section{Conclusies}

Een van de belangrijkste uitdagingen van het herstelrechtdiscours is de aandacht te verleggen van de 'communities of care' rondom de direct betrokkenen naar institutionele interventies, zoals werk, school, huisvesting, gezondheidszorg, enz. Door de individualisering van het probleem van misdaad is herstelrecht niet in staat om te gaan met sociale en structurele ongelijkheden. De link tussen het individu en impact op de gemeenschap blijft onduidelijk. Ook de band tussen staat en gemeenschap blijft naïef in het herstelrecht, waarbij, zoals Pavlich (2005) opmerkt, de gemeenschap van herstelrecht in wezen wordt gevormd door de staat (die voorziet in diensten). Voor schrijvers als Melucci is het creëren en onderhouden van openbare ruimten onafhankelijk van de overheid, een centrale voorwaarde voor de herdefiniëring van de democratie door nieuwe sociale bewegingen (Melucci, 1989). Herstelrecht is in de praktijk altijd afhankelijk geweest van de staat, mede door zijn nauwe relatie tot het strafrechtelijk systeem en de wetgeving, vooral in continentaal Europa. Deze paradoxale relatie tot zowel staat als gemeenschap maakt herstelrecht een potentieel krachtig discours, maar tegelijkertijd onkritisch ten opzichte van beide.

Herstelrecht moet deze kritische reflecties serieus nemen. Ten eerste zou het herstelrecht het naïeve gebruik van gemeenschap moeten opgeven. Hoewel we ons niet verzetten tegen het utopisch gebruik van de term, dienen we de complexiteit ervan te onderkennen. Er is geen statische gemeenschap te herstellen. Er zijn slechts zeer complexe en dynamische sociale aggregaten met verschillende machten, structuren en middelen. Het is nuttig om Pavlichs opvatting voor de geest te halen dat 'community' altijd een ethische kwestie is met betrekking tot een continu open, veranderbaar en toekomstgericht streven van samenzijn (Pavlich, 2005). Deze 'coming community ' (Agamben, 1993) is dus een voortdurende activiteit in plaats van een voltooid werk dat bewaard en gerestaureerd moet worden; een activiteit die de gevestigde orde en machtsverhoudingen voortdurend verstoort en transformeert. 
Ten tweede, terwijl herstelrecht geen panacee voor sociale rechtvaardigheid kan zijn, mag het niet in dezelfde val lopen die het beoogt te vermijden, namelijk door zich te beperken tot een individualisering van misdaad en de reacties daarop. Met andere woorden, misdaad moet niet zozeer worden beschouwd als louter schade, maar als een sociaal probleem, nauw verwant met sociale omstandigheden waarvoor niet alleen een individu maar de gehele samenleving verantwoordelijk is. Herstelgerichte praktijken zoals conferencing of circles zijn op de goede weg, want ze hebben het potentieel om te werken aan structurele problemen (Gaarder en Presser, 2008; Braithwaite, 2000). Die praktijken maken het mogelijk dat burgers discussiëren over en reflecteren op mogelijke verbanden tussen criminaliteit en sociale omstandigheden; aldus kan bewustwording ontstaan en kunnen strategieën worden ontworpen om sociale problemen aan te pakken (Pranis, 2001). Niettemin moet het herstelrecht niet alleen beperkt blijven tot reflectie, maar moeten allianties van organisaties worden gesmeed, zodat netwerken van verantwoordelijkheid kunnen ontstaan waarbinnen allerlei onrechtvaardigheden kunnen worden bestreden.

\section{Literatuur}

Aertsen, I. (2001). Slachtoffer-daderbemiddeling: een onderzoek naar de ontwikkeling van een herstelgerichte strafrechtsbedeling. Leuven: Leuven University Press.

Aertsen, I. (2008). Racak, Mahane Yehuda en Nyabyondo: herstelrecht between the formal and the informal. In: I. Aertsen, J. Arsovska, H. Rohne, M. Valiñas en K. Vanspauwen (Eds.), Restoring justice after large-scale violent conflicts. Kosovo, DR Congo and the IsraeliPalestinian case (pp. 413-443). Cullompton: Willan Publishing.

Aertsen, I., Mackay, R., Pelikan, C., Willemsens, J. en Wright, M. (2004). Rebuilding Community Connections - mediation and herstelrecht in Europe. Strassbourg: Council of Europe Publishing.

Agamben, G. (1993). The Coming Community. Minnesota: University of Minnesota Press.

Arendt, H. (1998). The human condition. Chicago: University of Chicago Press.

Braithwaite J. (1994). Thinking Harder about Democratising Social Control. In: C. Alder en J. Wundersitz (Eds.), Family Conferencing and Juvenile Justice: The Way Forward or Misplaced Optimism? (pp. 199-216). Canberra, AUS: Australian Institute of Criminology.

Braithwaite J. (1999). Restorative Justice: assessing optimistic and pessimistic accounts. Crime and Justice, 25, 1-128.

Braithwaite J. (2000). Repentance rituals and restorative justice. Journal of Political Philosophy, 8, 115-31.

Braithwaite, J. (2002). Herstelrecht and responsive regulation. Oxford: Oxford University Press.

Braithwaite, J. en Parker, C. (1999). Herstelrecht is republican justice. In: G. Bazemore en L. Walgrave (Eds.), Herstelrecht for juveniles: Repairing the harm by youth crime (pp. 103126). Monsey: Criminal Justice Press.

Braithwaite, J. en Pettit, Ph. (1992). Not just deserts. A Republican Theory of Criminal Justice. Oxford: Clarendon.

CEPEJ (European Commission for the Efficiency of Justice) (2007). Guidelines for a better implementation of the existing recommendation concerning mediation in penal matters. Strassbourg: Council of Europe. 
Christie, N. (1977). Conflicts as property. British Journal of Criminology 17(1), 1-15.

Crawford, A. (1997). The Local Governance of Crime. Oxford: Oxford University Press.

Crawford, A. (2010). Conceptual Links and Policy Challenges. In: Restorative Justice and Crime Prevention, prepared by the Italian Ministry of Justice, European Forum for Restorative Justice / Psychoanalytic Institute for Social Research, pp. 1-22, www. euforumrj.org.

Cunneen, C. (2010). Debating Restorative Justice. Oxford; Portland, Or.: Hart.

Cunneen, C. (2008). Understanding restorative justice through the lens of critical criminology. In: The Critical Criminology Companion (pp. 290-302). Sydney, NSW, Australia: Hawkins Press.

Cunneen C. en Hoyle C. (2010). Debating Restorative Justice. Oxford: Hart publishing.

Dryzek, J. (2010). Foundations and frontiers of deliberative governance. Oxford: Oxford University Press.

Dzur, A. en Olson, S. (2004). The value of community participation in restorative justice. Journal of Social Philosophy, 35(1), 91-107.

Dzur, A.W. (2003). Civic Implications of Restorative Justice Theory: Citizen Participation and Criminal Justice Policy. Policy Sciences 36, 279-306.

Elliott, D.E., \& Gordon, R.R.M. (2005). New Directions In Restorative Justice: Issues, Practice, Evaluation. Devonshire: Willan Publishers.

Elster, J. (Ed.) (1998). Deliberative democracy. Cambridge Studies in the Theory of Democracy, Cambridge: Cambridge University Press.

Froestad. J. en Shearing, C. (2007). Beyond restorative justice - Zwelethemba, a future focused model using local capacity conflict resolution. In: R. Mackay, M. Bosnjak, J. Deklerck, C. Pelikan, B. van Stokkom en M. Wright (Eds.), Images of Restorative Justice Theory (pp. 5-35). Frankfurt/Main: Verlag für Polizeiwissenschaft.

Gaarder E. en Presser L. (2008). A feminist vision of justice? The problems and possibilities of restorative justice for girls and women. In: D. Sullivan en L. Tifft (Eds.), Handbook of Restorative Justice (pp. 483-494). London: Routledge.

Giddens, A. (1998). The Third Way. The Renewal of Social Democracy. Cambridge: Polity Press.

Gordon, D. (2006). Public-empowering justice. Arguments from effectiveness, legitimacy and democracy, and the South African case. Punishment and Society, 9(1): 49-66.

Holston, J. (2008). Insurgent citizenship: Disjunctions of democracy and modernity in Brazil. Princeton: Princeton Univ. Press.

Hudson, B. (2003). Restorative justice: the challenge of sexual and racial violence. In: G. Johnstone, A Restorative Justice Reader: Texts, Sources, Context (pp. pp. 438-450). Cullompton: Willan.

LaPrairie, C. (1995) Community Justice or Just Communities? Aboriginal Communities in Search of Justice. Canadian Journal of Criminology, 37: 521-45.

Melucci, A. (1989). Nomads of the Present: Social Movements and Individual Needs in Contemporary Society. London: Hutchinson Radius.

Pali, B. en Pelikan, C. (2010). Building social support for restorative justice: Media, civil society, and citizens. Leuven: European Forum for Restorative Justice.

Pavlich, G. (2005). Governing Paradoxes of Restorative Justice. London: Glasshouse Press.

Polk, K. (1994). Family conferencing: theoretical and evaluative concerns. In: C. Alder en J. Wundersitz (Eds.), Family Conferencing and Juvenile Justice: The Way Forward or Misplaced Optimism (pp. 1-20). Institute of Criminology. Canberra, Australia.

Pranis, K. (2001). Restorative justice, social justice and the empowerment of marginalized populations. In: G. Bazemore en M. Schiff (Eds.), Restorative Community Justice: Re- 
pairing the Harm and Transforming Communities (pp. 127-149). Cincinnati: Anderson Publishing.

Price, B. (2004). Does restorative justice challenge systematic injustices? In: H. Zehr en B. Toews (Eds.), Critical Issues in Restorative Justice. Cullompton, Devon, UK: Willan Publishing.

Schweigert, F.J. (1999). Moral education in victim offender conferencing. Criminal Justice Ethics, 18(2), 29-40.

Shapland, J. (Ed.) (2008). Justice, community, and civil society: A contested terrain. Cullompton: Willan Publishing.

Shearing, C. en Wood, J. (2003). Nodal governance, democracy, and the new 'denizens'. Journal of Law and Society 30, 400-419.

Stringer, E.T. (1999). Action Research (second ed.). London: Sage.

UN Office on Drugs and Crime (2006). Handbook of Restorative Justice Programmes. Vienna: UNODC.

Vanfraechem, I. (2007). Community, society and state in restorative justice: an exploration. In: R. Mackay, M. Bosnjak, J. Deklerck, C. Pelikan, B. van Stokkom en M. Wright (Eds.), Images of Restorative Justice Theory (pp. 73-91). Frankfurt, Germany: Verlag fur Polizeiwissenschaft.

Vanfraechem, I. (2003) Implementing Family Group Conferences in a Legalistic System. The example of Belgium. In: L. Walgrave (Ed.), Repositioning Restorative Justice. Restorative Justice, Criminal Justice and Social Context (pp. 313-327). Cullompton: Willan Publishing.

Vanfraechem, I., Aertsen, I. en Willemsens, J. (Eds.) (2010). Restorative Justice Realities. Empirical research in a European context. Den Haag: Eleven International Publishers.

Walgrave, L. (Ed.) (2002). Restorative Justice and the Law. Cullompton: Willan Publishing. Willemsens, J. en Walgrave, L. (2007). Regional Review: Europe. In: G. Johnstone \& D. van Ness, Handbook of Restorative Justice (pp. 468-533).

Young, J. (2000). The Maintenance of Order among Lightly Engaged Strangers.

Zehr, H. (1990). Changing Lenses: A New Focus for Crime and Justice. Herald Press.

Zinsstag, E. en Vanfraechem, I. (Eds.) (2012). Conferencing and Restorative Justice: International Practices and Perspectives. Oxford: Oxford University Press.

Zinsstag, E., Teunkens, M. en Pali, B. (2011). Conferencing: a way forward for restorative justice in Europe. Leuven: European Forum for Restorative justice. 